\title{
2:1 Block with Wenckebach Mechanism in Children Due to Different Etiologies F Laloğlu ${ }^{1}, \mathrm{~N} \mathrm{Ceviz}^{1}, \mathrm{H}$ Keskin $^{2}, \mathrm{H}_{\text {Olgun }}{ }^{1}$
}

\begin{abstract}
Objective: In children 2:1 Atrioventricular Block (AVB) with Wenckebach mechanism is a rare entity.

Subjects and methods: In 7 children, 2:1 Atrioventricular Block (AVB) with Wenckebach mechanism was detected. The clinical features of these children are retrospectively evaluated. Results: All patients were asymptomatic. In all, concomitant first-degree AV block and/or periodic AV Wenckebach block suggested the presence of 2:1 block with Wenckebach mechanism. In 3 patients, this conclusion was supported by demonstration of improved AV conduction with enhanced sinus rates during treadmill test or atropine administration. In two, intracardiac electrophysiological was performed and showed a prolonged atrium-His interval. Four patients had congenital or acquired heart disease. During a median follow-up duration of 14.4 months no significant event was observed.

Conclusion: In children, 2:1 AV block with Wenckebach mechanism seems a relatively benign process.
\end{abstract}

Keywords: 2:1 Atrioventricular block, bradycardia, children, wenckebach

From: ${ }^{1}$ Atatürk University Faculty of Medicine, Department of Pediatrics, Division of Pediatric Cardiology, and ${ }^{2}$ Atatürk University Faculty of Medicine, Department of Pediatrics, Erzurum, Turkey.

Correspondence: Dr N Ceviz, Department of Pediatrics, Division of Pediatric Cardiology, Faculty of Medicine, Atatürk University, Erzurum,Turkey. Fax: +90 (442) 231 1111, email: ceviznaci@yahoo.com 


\section{INTRODUCTION}

In 2:1 atrioventricular block (AVB), a ventricular complex follows every second atrial complex. The atrial rate (PP interval) and the PR interval of the conducted beat are normal. It is usually due to Mobitz I mechanism (block in the AV node) (1). Although occurrence of 2:1 block due to Mobitz I mechanism has been reported in adults (2). No study from children has been reported. In this paper we report our experiences from 7 children with 2:1 AVB due to Mobitz I mechanism.

\section{MATERIALS AND METHODS}

Databases of the division of Pediatric Cardiology were analized and the list of the children with the diagnosis of 2:1 AVB due to Mobitz I mechanism was found. The clinical characteristics of the children were analyzed retrospectively in terms of demographic features, present diseases, clinical presentations, diagnostic methods and follow-up results.

\section{RESULTS}

A total of 7 children were found to be diagnosed as having 2:1 AVB due to Mobitz I mechanism. Median age at diagnosis was 2.5 \pm 4.8 years (range 2.5-15 years). All but one was female. Individual clinical characteristics of the patients are given in table 1. In two patients electrophysiological study was performed (Table 2).

Four patients were referred to our clinic for different reasons; evaluation for low heart rate detected during examination $(n=2)$, easy fatigability $(n=1)$, Mobitz type II AVB in Holter recording $(n=1)$, fist attack of acute rheumatic fever (ARF) $(n=1)$. Two patients were diagnosed on follow-up evaluations for rheumatic heart disease $(n=1)$ and previous cardiac surgery $(n=1)$. 
2:1 AV block was detected on the first admission in 6 patients, on the postoperative $6^{\text {th }}$ month control in one (Pt 2) and on the $6^{\text {th }}$ month control after the first attack of ARF in one (Pt 4) patient.

Electrocardiography and Holter findings at the diagnosis of 2:1 AVB are given in table 3. 2:1 AVB was present in the surface ECG in two patients, however in Holter recordings in all patients. In one patient (Pt 3), nonsustained 2:1 AVB episode was detected on Holter recording that was applied for a study (3). In all remaining patients longer periods of 2:1 AVB episodes were present in Holter recordings. No pauses longer than 2 seconds were detected.

In 3 patients 1:1 AV conduction was observed during advanced stages of treadmill test (with narrow QRS in two, and with wide QRS due to postoperative right bundle branch block in one). In one patient with sustained 2:1 block, AV conduction returned to 1:1 conduction after atropine administration. In remaining three patients any test for evaluation of AV conduction during increased heart rate was not available (due to short attack of 2:1 AVB in one, and very short investigation period in 2 patients).

In two patients control follow-up visits was not available. In remaining 5 patients median follow-up period was 14.4 months. During this period no new 2:1 AVB episodes were observed in repeated Holter recordings in two patients. In one, only first degree AVB and Wenckebach block episodes were observed. In 2 patients sustained 2:1 AVB episodes were continued. None of the patients had new and significant symptoms. ,

\section{DISCUSSION}

Mobitz Type I second degree AVB (Wenckebach block or phenomenon) is generally a benign atrioventricular conduction problem and there is a progressive lengthening of the PR interval culminating in a dropped ventricular beat (1). 
Mobitz Type II second degree AVB usually is caused by conduction block within the HisPurkinje system. This conduction abnormality is shown on the ECG as a sudden failure of a P wave to conduct to the ventricle, with no change in the PR interval either before or after the nonconducted P wave (4).

In 2:1 AVB, a ventricular complex follows every second atrial complex. The atrial rate and the PR interval of the conducted beat are normal. These are usually due to Mobitz I mechanism (block in AV node), particularly when associated with normal QRS complexes, but His bundle recording may be necessary to determine whether the block occurs in the upper AV node or at the level of His bundle, in occasional cases (1). Diagnostic clues to the site of block include the following;

Concomitant first-degree AV block, periodic AV Wenckebach, or improved conduction (1:1) with enhanced sinus rates of sympathetic input suggests a more proximal interruption of conduction (i.e., Mobitz type I mechanism).

Concomitant bundle-branch block, fascicular block, worsened conduction $(3: 1,4: 1$, etc) with enhanced sympathetic input localizes the site of block more distally (Mobitz type II mechanism) (5).

In all of our patients, concomitant first-degree AV block and/or periodic AV Wenckebach block suggested the presence of 2:1 block with Wenckebach mechanism. In 3 patients, this conclusion was supported by demonstration of improved AV conduction $(1: 1)$ with enhanced sinus rates during treadmill test or atropine administration.

In two of our patients the 2:1 AVB was sustained, and one had a previous cardiac surgery with complete RBBB. In these patients intracardiac electrophysiological study suggested the presence of a suprahisian conduction delay. In electrophysiological study normal AH values in children range from 50 to 120 miliseconds, and normal HV values range from 2550 miliseconds. A prolonged AH interval indicates a conduction delay in the AV node, and a 
prolonged HV interval suggests a conduction delay His-Purkinje system (6). In our patients the AH intervals were 150 and $128 \mathrm{~ms}$.

We could not found any information about the prognosis of 2:1 AVB with Wenckebach mechanism in children. Our limited data suggests a good prognosis for these patients at least during the mid-term follow-up.

\section{CONCLUSION}

The findings of the study suggest that the clues indicating a Wenckebach mechanism in children with 2:1 AVB can be obtained by noninvasive techniques. In children with sustained 2:1 AVB intracardiac electrophysiological study can help the differentiation, and the prognosis seems good.

\section{AUTHORS' NOTE}

Concept - N.C., H.O.; Design - H.K., F.L.; Supervision - N.C.; Materials -H.O.; Data Collection \&/or Processing - H.K., F.L.; Analysis \&/or Interpretation - N.C; Literature Search - N.C.; Writing Manuscript - N.C.; Critical Reviews - N.C., H.O. 


\section{REFERENCES}

1. Park MK, Guntheroth WG. How to Read Pediatric EKGs. USA: Mosby Elsevier; 2006.

2. Izumi K, Ito T, Ota S. Wenckebach periods associated with high grade second degree (2: 1 and $3: 1)$ A-V block. Jpn Heart J. 1975; 16: 620-8.

3. Karacan M, Isikay S, Olgun H, Ceviz N. Asymptomatic rhythm and conduction abnormalities in children with acute rheumatic fever: 24-hour electrocardiography study. Cardiol Young. 2010; 20: 620-30.

4. Brady PA. Specific Arrhythmias and Syncope. In: Ghosh AK ed. Mayo Clinic Internal Medicine Board Review. New York: OUP; 2010: 68-70. .

5. Cooper DH. Bradyarrhythmias and Permanent Pacemakers. In: Cuculich PS, Kates AM eds. The Washington Manual Cardiology Subspecialty Consult. China: Lippincott Williams and Wilkins; 2009: 246-56.

6. Pass RH, Walsh EP. Intracardiac Elektrophysiologic Testing in Pediatric Patients. In: Walsh EP, Saul JP, Triedman JK eds. Cardiac Arrhythmias in Children and Young Adults with Congenital Heart Disease. Philadelphia: Lippincott Williams and Wilkins; 2001: 67-71. . 
Table 1: Individual clinical characteristics of the patients

\begin{tabular}{|c|c|c|c|c|c|c|c|}
\hline & Patient 1 & Patient 2 & Patient 3 & Patient 4 & Patient 5 & Patient 6 & Patient 7 \\
\hline Age at diagnosis (Y) & 3 & 7 & 15 & 13 & 2,5 & 5 & 7 \\
\hline Gender & $\mathrm{F}$ & M & $\mathrm{F}$ & $\mathrm{F}$ & $\mathrm{F}$ & $\mathrm{F}$ & $\mathrm{F}$ \\
\hline Clinical presentation & $\begin{array}{l}\text { Low } \\
\text { heart rate }\end{array}$ & $\begin{array}{l}\text { Routine } \\
\text { control for } \\
\text { operated } \\
\text { VSD+ } \\
\text { ASD }\end{array}$ & Arthritis & $\begin{array}{l}\text { Routine } \\
\text { control } \\
\text { for RHD }\end{array}$ & $\begin{array}{l}\text { Fatigue, } \\
\text { murmur }\end{array}$ & $\begin{array}{l}2: 1 \mathrm{AVB} \text { in } \\
\mathrm{ECG}\end{array}$ & $\begin{array}{l}\text { Low } \\
\text { heart rate }\end{array}$ \\
\hline Echocardiography & Normal & $\begin{array}{l}\text { Operated } \\
\text { VSD+ } \\
\text { ASD }\end{array}$ & $\begin{array}{l}\mathrm{ARF}, \\
\text { aortic and } \\
\text { mitral } \\
\text { regurgitati } \\
\text { on }\end{array}$ & $\begin{array}{l}\text { RHD, } \\
\text { aortic and } \\
\text { mitral } \\
\text { regurgitati } \\
\text { on }\end{array}$ & Normal & $\begin{array}{l}\text { Mild } \\
\text { valvular } \\
\text { pulmonary } \\
\text { stenozis }\end{array}$ & Normal \\
\hline Electrocardiography & FDAVB & RBBB & FDAVB & FDAVB & $2: 1 \mathrm{AVB}$ & FDAVB & $\begin{array}{l}\text { WB+ } \\
2: 1 \text { AVB }\end{array}$ \\
\hline $\begin{array}{l}\text { 24-hour ECG } \\
\text { monitorization }\end{array}$ & $\begin{array}{l}\text { FDAVB+ } \\
\text { WB+ } \\
2: 1 \text { AVB }\end{array}$ & $\begin{array}{l}\text { WB+ } \\
2: 1 \text { AVB }\end{array}$ & $\begin{array}{l}\text { FDAVB+ } \\
\text { WB+ } \\
2: 1 \text { AVB }\end{array}$ & $\begin{array}{l}\text { FDAVB+ } \\
\text { WB+ } \\
2: 1 \text { AVB }\end{array}$ & $\begin{array}{l}\text { FDAVB+ } \\
\text { WB+ } \\
2: 1 \text { AVB }\end{array}$ & $\begin{array}{l}\text { FDAVB+ } \\
\text { WB+ } \\
2: 1 \text { AVB }\end{array}$ & $\begin{array}{l}\text { FDAVB } \\
+\mathrm{WB}+ \\
2: 1 \mathrm{AVB}\end{array}$ \\
\hline $\begin{array}{l}\text { Follow-up duration } \\
\text { (months) }\end{array}$ & 9,7 & 14,4 & 38,1 & 66,8 & $\begin{array}{l}\text { No } \\
\text { follow-up }\end{array}$ & $\begin{array}{l}\text { No } \\
\text { follow-up }\end{array}$ & 11,7 \\
\hline $\begin{array}{l}\text { Electrophysiological } \\
\text { study }\end{array}$ & Available & Available & NA & NA & NA & NA & NA \\
\hline
\end{tabular}

Y: Years, F: Female, M: Male, VSD: Ventricular Septal Defect, ASD: Atrial Septal Defect, RHD: Rheumatic Heart Disease, AVB: Atrioventricular Block, ECG: Electrocardiography, ARF: Acut Rheumatic Fever, FDAVB: First- Degree Atrioventricular Block, RBBB: Right Bundle Branch Block, WB: Wenckebach Block, y:years 
Table 2: Electrophysiological study results in two patients

\begin{tabular}{llll}
\hline $\begin{array}{l}\text { Patient } \\
\text { no }\end{array}$ & $\begin{array}{l}\text { AV node Wenckebach } \\
\text { point (ms) }\end{array}$ & $\begin{array}{l}\text { AH interval } \\
(\mathbf{m s})\end{array}$ & $\begin{array}{l}\text { HV interval } \\
(\mathbf{m s})\end{array}$ \\
\hline $\mathbf{1}$ & 300 & 156 & 30 \\
$\mathbf{2}$ & 570 & 128 & 50 \\
\hline
\end{tabular}

AV: Atrioventricular, AH: Atrial-His, HV: His-Ventricular

Table 3: Electrocardiography and Holter findings at the diagnosis of 2:1 Atrioventricular block

\begin{tabular}{|c|c|c|c|c|}
\hline $\begin{array}{l}\text { Patient } \\
\text { no }\end{array}$ & $\begin{array}{l}\text { Surface } \\
\text { electrocardiography }\end{array}$ & & Holter & \\
\hline & & Rhythm & SDNN & Longest RR \\
\hline 1 & FDAVB & $\begin{array}{l}\text { FDAVB, Wenckebach } \\
\text { blok, 2:1 AVB }\end{array}$ & 67 & 1429 \\
\hline 2 & NSR, RBBB & $\begin{array}{l}\text { Wenckebach blok, 2:1 } \\
\text { AVB }\end{array}$ & 278 & 2000 \\
\hline 3 & NORMAL & $\begin{array}{l}\text { Wenckebach blok, 2:1 } \\
\text { AVB }\end{array}$ & 57 & 1070 \\
\hline 4 & FDAVB & $\begin{array}{l}\text { FDAVB, Wenckebach } \\
\text { blok, 2:1 AVB }\end{array}$ & 101 & 1640 \\
\hline 5 & 2:1 AVB & $\begin{array}{l}\text { FDAVB, Wenckebach } \\
\text { blok, 2:1 AVB }\end{array}$ & 115 & 1671 \\
\hline 6 & FDAVB & $\begin{array}{l}\text { FDAVB, Wenckebach } \\
\text { blok, 2:1 AVB }\end{array}$ & 100 & 1500 \\
\hline 7 & $\begin{array}{l}\text { Wenckebach blok, } \\
\text { 2:1 AVB }\end{array}$ & $\begin{array}{l}\text { FDAVB, Wenckebach } \\
\text { blok, 2:1 AVB }\end{array}$ & 306 & 1980 \\
\hline
\end{tabular}

SDNN: Standart Deviation of NN Intervals, FDAVB: First- Degree Atrioventricular Block, AVB: Atrioventricular Block, NSR: Normal Sinus Rhythm, RBBB: Right Bundle Branch Block. 